Parker, C.M., Groh, V., Band, H., Porchlli, S.A., Morita, C.T., Fabi, M., Glass, D., STrominger, J.L. \& Brenner, M.B. (1990), Evidence for extrathymic changes in the T-cell receptor $\gamma / \delta$ repertoire. $J$. exp. Med., 171, 1597-1612.

Porcelli, S.A., Brenner, M.B., Greenstein, J.L., Balk, S.P., Terhorst, C. \& Bleicher, P.A. (1989), Recognition of cluster of differentiation 1 antigens by human CD4-CD8cytotoxic T lymphocytes. Nature (Lond.), 341, 447-450.

Ratasekhar, R., Sim, G.-K. \& Augustin, A. (1990), Self heat shock and $\gamma \delta$ T-cell reactivity. Proc. nat. Acad. Sci. (Wash.), 87, 1767-1771.

Rivas, A., Koide, J., Cleary, M. \& Engl.eman, E.G. (1989), Evidence for involvement of the $\gamma \delta \mathrm{T}$-cell antigen receptor in cytotoxicity mediated by human alloantigen specific T-cell clones. J. Immunol., 142, 1840-1846.

Rust, C.J.J., Verkeck, F., Vietor, H. \& Koning, F. (1990), Specific recognition of staphylococcal enterotoxin $A$ by human $Y$ cells bearing receptors with the $V_{\gamma} 9$ region. ivature (Lond.), 346, 572-574.

SPITS, H., Paliard, X., EnGelhard, V.H. \& de VRIES, J.E. (1990), Cytotoxic activity and lymphokine production of T-cell receptor (TCR)- $\alpha \beta^{+}$and TCR- $\delta^{+}$cytotoxic T-lymphocyte (CTL) clones recognizing HLA-A2 and HLA-A2 mutants. Recognition of TCR- $\gamma^{+}$CTL clonss is affected by mutations at positions 152 and 156. J. Immunol., 144, 4156-4162.

Ullaich, R., Schieferdecker, H.L., Ziegler, K., Riecken, E.O. \& Zeitz, M. (1990), y $\delta$ T cells in the human intestine express surface markers of activation and are preferentially located in the epititelium. Cell. Immunol., 128, 619-627.

Vidovic, D., Roglic, M., McKune, K., Guerder, S., MacKay, C. \& Dembic, Z. (1989), Qa-1-restricted recognition of foreign antigen by a T-cell hybridoma. Nature (Lond.), 340, 646-650.

Young, R.A. \& Elliot, T.J. (1989), Stress proteins, infection and immune surveillance. Cell, $59,5-8$.

\title{
POTENTIAL ROLE OF $\gamma \delta$ T CELLS IN AUTOIMMUNE DISEASES
}

\author{
J. Holoshitz \\ Department of Internal Medicine \\ University of Michigan School of Medicine \\ Ann Arbor, MI (USA) 48109-053I
}

More than half a decade after their identification, $\gamma \bar{\delta} T$ cells continue to challen e immunolcgists. Their antigenic specificity, antigen recognition process and biological role are still largely elusive. Paradoxically, increased frequencies of $\gamma \delta \mathrm{T}$ cells can be found in two apparently polar situations : immunodeficiency on the one hand, and hyperimmune states such as autoimmunity and inflammatory conditions on the other hand. The hypothesis presented here postulates that $\gamma \delta$ T cells, vital remnants of a primitive cellular immune system, are called upon in situations where the more evolutionarily advanced and "sophisticated" cellular immune barrier, the $\alpha \beta$ T-cell-dependent system, is failing. Under certain circumstances, this may result in autoimmunity.

It has long been noticed that immunodeficiency and autoimmunity, two apparently conflicting clinical situations, can co-exist. For example, patients with agammaglobulinaemia have a higher frequency of arthritis clinicaily indistinguishable from rheumatoid arthritis (RA) (Good et al., 1957). Patients with selective IgA deficiency have a greater than expected occurrence of systemic hupus erythematosus (Cassidy et al., 1969) and insulin-dependent dia- 
betes mellitus (Hoddincot et al., 1982). Autoimmune phenomena have also been observed in patients with AIDS (Kopelman and Zolla-Pazner, 1988; Berman et al., 1988). In addition, rodents rendered immunodeficient by cyclosporine $A$, by total lymphoid irradiation or by anti-T-cell antibodies may develop autoimmune sequelae (Trentham et al., 1984; Sakuguchi and Sakaguchi, 1988, 1989).

$T$ cells bearing the $\gamma \delta$ T-cell receptor (TCR) have been identified in higher frequencies in spontaneous or induced immunodeficiencies. Patients with ataxia teleangiectasia, a syndrome associated with immunodeficiency, have been reported to display a high frequency of $\gamma \delta \mathrm{T}$ cells in their peripheral blood (Carbonari et al., 1990). In addition, some patients with Wiskott-Aldrich syndrome and severe combined immunodeficiency have up to $68 \%$ circulating $\gamma \delta \mathrm{T}$ cells (Morio et al., 1990). Long-term $\gamma \delta \mathrm{T}$-cell lines were isolated from a patient with immunodeficiency (Brenner et al., 1987). Immunodeficiency induced by cyclosporine $A$ in mice is associated with a relative increase in $\gamma^{\delta}$ cells (Jenkins $e t a^{\prime} .$, 1988). Taken together, the above observations may suggest that inherent or acquired defects in development or function: of TCR $\alpha \beta$ cells may create suitable conditions for less "sophisticated", potentiailiy autoaggressive celfis, such as TCR $\gamma^{o}$ cells, to expand and result in autoimmunity.

Could "spontaneously" occurring autoimmune conditions which have no clinically apparent immurodeficiency, such as RA, stem from a similar pathogenetic mechanism ? TCR $\gamma \delta$ cells and cells with the phenotype CD3-CD4-CD8 - ("double-negative" cells, which are mostly TCR $\gamma \delta$ cells) have been implicated in a number of hyperimmune conditions in mice including models of lupus (Datta et al., 1987) and autoreactivity (Morriset et al., 1988). Double-negative murine "r cells were found capable of breaking oral tolerance (Kitanura et al., 1987). In humans, double-negative cells have been found in thyroid tissue in Hashimoto thyroiditis (Del Prete et al., 1986).
Atu idance of double-negative TCR $\gamma \delta$ cells has also been noticed in the lungs of patients with sarcoidosis (Baibi et al., 1990) and in the synovial fluid of patients with RA (De Maria et al., 1987; Brennan et al., 1988a; Haynes et al., 1988; Holoshitz et al., 1989; Reme et al., 1990).

The role of $\gamma \delta \mathrm{T}$ cells in the pathogenesis of RA has not been defined yet. However, a number of observations sug est that they may be pathogenically important. $T$ cells in general are thought to play an important role in the pathogenesis of RA. Histologically, the synovial membrane in RA is infiltrated by $T$ lymphocytes, predominantly of the CD4+ phenotype. These T cells show markers of activation suck: as receptors for IL-2 and HLA class II molecules (Klareskog et al., 1982). Selective elimination of CD4 + T cells by procedures such as total lymphoid irradiation (Tanay et al., 1987) can lead to improvement of the disease. The specificity of synovial $T$ cells is unknown. While an antigennon-specific $T$-cell activation may play a role in perpetuation of the disease (Haynes et al., 1988), the close association of RA with certain HLA DR alleles suggests that recognition of an arthritogenic antigen may be involved in triggering the disease.

Two-thirds of patients with seropositive RA display the HLA DR4 phenotype (Stastny, 1978). Consistent with the "shared epitope" theory (Gregersen et al., 1987), recent molecular data suggest that many of the remaining one-third of DR4-negative patients may share with the DR4-positives a typical nucleotide sequence at the third hypervariable region of the DR $\beta 1$ gene (Nepom et al., 1989). This region of the class II $\beta$ chain is predicted to comprise part of the class II helix critical for specific interaction with antigenic peptides and the TCR (Brown et al., 1988). Mutations in this region have been shown to alter $T$-cell immure responses and susceptibility to autoimmune disease in mice (Christadoss et al., 1985). Thus, it is conceivable that susceptibility to RA is related to the ability of these regions to present antigens to $T$ cells. 
As mentioned above, the identity of the putative antigen is still unknown. However, the possibility that mycobacterial heat shock proteins (HSP) are playing a role is emerging. Synovial T lymphocytes from patients with RA make a vigorous proliferative response to mycobacterial antigen, in particular to the $65-\mathrm{Kda}$ mycobacterial HSP (Holoshitz et al., 1986; Res et al., 1988). These studies have shown that the proliferative responses to the mycobacterial protein were higher in synovial fluids than those in paired peripheral blood. The reactivity was characteristically found in early stages of joint inflammation, suggesting that $T$-cell reactivity to $H S P$ may be involved in triggering the arthritis. Additional evidence for the potential arthritogenicity of HSP comes from studies of adjuvant arthritis, a rat model of RA. From rats afflicted with this disease, a T-cell line (Holoshitz et al., 1983) and clones (Holoshitz et al., 1984, 1988) capable of either transferring or protecting against arthritis have been isolated. These clones recognize an epitope within amino acids $180-188$ of the mycobacterial $65-\mathrm{kDa}$ HSP (Van Eden, W. et al., 1988).

HSP are a family of highly conserved proteins which can be induced in prokaryotic and eukaryotic cells by heat or other stress conditions. While their biological role is not entirely understood, these findings have fostered the idea that antigenic mimicry might be involved in the pathogenesis of RA and other inflammatory arthritic conditions. According to this hypothesis, genetical!y susceptible indiviauals may develop an immune response to bacterial HSP that is cross-reactive with self. The resultant immune injury to target cells may in turn induce further expression of HSP and lead tre chronic self perpetuation of the disease. However, it is possible that the reactivity of synovial $T$ cells to mycobacterial proteins is an effect of the disease rather than a cause. It is possible that tissue injury in a variety of inflammatory arthritic conditions, regardless of the precipitating initial events, results in expression of new antigens on the synovial cell surface which cross-react with the mycobacterial antigens.
Given the close association between certain DR alleles and RA susceptibility, it would seem reasonable to predict that recognition of a specific antigen in the joint by $\alpha \beta \mathrm{T}$ cells would involve a clonally restricted population of $T$ cells. An increasing body of evidence suggests that this is probably not the case. Initial studies using Southern blot analysis of TCR $\beta$ genes showed distinct rearrangements in long-term cultured synovial $T$ cells, suggesting clonal dominance (Stamenkovic et al., 1988). However, the possibility that the long term tissue culture conditions in that study could have induced in vitro selection was suggested by the finding of similar clonal dominance in cultures obtained from patients with osteoarthritis (Stamenkovic et al., 1988). Moreover, recent studies failed to demonstrate $\beta$-chain gene rearrangement in any one of 15 fresh synovial fluid cell preparations from RA patients (Keystone et al., 1988) or predominant rearrangements among 40 RA synovial fluid $T$-cell clones (Duby et al., 1989). Other recent studies reached similar conclusions (Savill et al., 1987; Brennan et al., 1988b). Although these results question the clonality of $\alpha \beta$ T cells in RA synovial effusions, they do not exclude the role of antigen-specific $\mathrm{T}$-cell responses in RA. It is possible that different TCR are capable of recognizing one or more epitopes on the target antigen. It is also possible that a small minority of antigen-specific T-cell clones initiate an autoaggressive process which can be perpetuated by recruitment and activation of a polyclonal $\mathbf{T}$-cell population. These results provide a rationale for directing more attention to $\gamma \delta \mathrm{T}$ cells.

As mentioned above, synovial effusions of RA patients contain a high number of T cells bearing the $\gamma \delta$ TCR. Their percentage in synovial effusions was found to be between two-fold to four-fold that in normal peripheral blood. Furthermore, in some of these studies (Brennan et al., 1988a; Holoshitz et al., 1989; Reme et al., 1990), most, if not all, of the $\gamma \delta \mathrm{T}$ cells stained positively with the monoclonal antibody $\mathrm{Ti}-\gamma \mathrm{A}$, which detects TCR $\gamma$ chains with the particular rearrangement : $V_{\gamma} 9 J_{\gamma} P C_{\gamma} 1$ (Triebel et al., 1988). 
Thus, while there is no evidence for $\alpha \beta$ clonality, a $\gamma \delta$ T-cell population, possibly oligoclonal, preferentially accumulates in RA synovial fluids. It is quite interesting that peripheral TCR $\gamma \delta$ $T$ cells and TCR $\gamma \delta$ cells isolated from synovial fluid and thymus were found to recognize mycobacterial antigens, including the mycobacterial 65-kDa HSP (Holoshitz et al., 1989; Janis et al., 1989; O'Brien et al., 1989; Haregewoin et al., 1989; Modlin et al., 1989; Kabelitz et al., 1990). With one exception (Haregewoin et al., 1989), all studies have shown that reactivity of $\gamma \delta$ $\mathrm{T}$ cells to mycobacteria was MHCunrestricted. Studies of the structure of the TCR chains of mycobacteriareactive $T$-cell clones revealed a limited receptor repertoire. For example, human inycobacteria-reactive $\gamma \delta$ T-cell clones were found to uniformly express the $\mathrm{V}_{\gamma} 9 . \mathrm{J} \gamma \mathrm{PC} \gamma \mathrm{l}$ rearrangement, paired with V $\delta 2$-bearing TCR $\delta$ chain (Holoshitz et al., 1989; Kabelitz et al., 1990; Holoshitz et al., unpublished results), and murine mycobacteriareactive $\gamma \hat{o} \mathrm{~T}$ ceilis all expressed the $\mathrm{V}_{\gamma} \mathrm{ijC}^{4} 4$ rearrangement paired with a Vó6-bearing $\delta$ chain (Happ et al., 1989). Limited V-region usage and $\mathrm{MHC}$ nonrestricted recognition of mycobacteria are reminiscent of bacterial "superantigen"' recognition by $\alpha \beta$ cells. Recent results from the author's laboratory indicate that, in addition to their reactivity to the mycobacterial superantigen-like moeity, $\gamma \delta \mathrm{T}$ cells can recognize nominal antigenic peptides (Holoshitz et al., in preparation).

The basic hypothesis presented here is that TCR rô cells and perhaps other "immature" cells play a role in triggering the synovitis of RA. It is hypothesized that RA-susceptible individuals cannot raise an adequate $T$-cell response to certain foreign antigens due to holes in their $\alpha \beta$ T-cell repertoire. Patients with RA have been found to display an impaired immune response to EBV (Depper and Zvaifler, 1981) and tetanus toxoid (Devey et al., 1987). In the case of EBV, sequence homology between the EBV glycoprotein gp110 and the third hypervariable region of the RAassociated DR $\beta 1$ chain was noticed (Roudier et al., 1988). It is hypothesized that a number of potential RA-inciting antigens might have sequence homology with either the "bare" DR $\beta 1$ chain or with a combination of DR $\beta 1$ and a self peptide occupying the MHC groove. Due to self tolerance, these antigens would not be recognized by $\alpha \beta$ $T$ cells. Instead, they will be presented to $\gamma \delta \mathrm{T}$ cells by a relatively nonpolymorphic RA-associated $\mathrm{MHC}$ molecule such as DRw53 (Merryman et al., 1989) or by another non-MHC molecule in linkage disequilibrium with DR4. (Experimental data supporting such nominal antigen recognition are currently being accumulated in the author's laboratory.)

The vast majority of indiv duals with DR alleles that confer susce|jtibility to RA do not develop arthritis. In a small minority of individuals, this otherwise safe and effective $\gamma \delta$ T-cell immune response may result in $\mathrm{RA}$ due to other, non-MHC genes (Go et al., 1987). Such putative polymorphic genes may encode products capable of enhancing activation of $\gamma \delta \mathrm{T}$ cells and/or migration of these cells to the tairat organs. The accumulation of $\gamma \delta T$ cells in the synovium may be due to in situ activation by either the nominal antigen, the mycobacterial superantigen, or self sonstituents of the joint mimicking those antigens. The locally activated yô $T$ cells could release lymphokines capable of polyclonal activation of $\alpha \beta \mathrm{T}$ cells (Ferrick $e t$ al., 1989) and stimulation of macrophages (Modlin et al., 1989), leading to the formation of a pannus. While $\gamma \delta \mathrm{T}$ cells would have a role in triggering the inflammatory process, according to this hypothesis, the effector role is played by polyclonal CD4+ $T$ cells. Elimination of such cells has been reported to yield temporary relief of RA (Tanay et al., 1987).

In summary, it is hypothesized that $\gamma \delta T$ cells are used as an aiternative defence mechanism in situations of $\alpha \beta$ T-cell-dependent immunodeficiency. An analogous situation of "limited immunodeficiency" may exist in RA when, due to their amino acid sequence homology to the DRB chain, some fc reign antigens are tolerated by $\alpha \beta$ $T$ cells. The impaired immune defence 
against the foreign antigen is partially compensated by activated $\gamma \delta \mathrm{T}$ cells. The $\gamma \delta$ T-cell response, augmented with the aid of non-MHC gene products, may result in arthritis. This hypothesis is not free of pitfalls; however, it offers a plausible explanation to some puzzling questions regarding $\mathbf{R A}$ and possibly other autoimmune conditions. It is conceivable that similar constellations of certain $\mathrm{MHC}$ alleles, foreign antigens and conducive non-MHC genes can be implicated in other MHC-associated autoimmune diseases.

Dr. Holoshitz is supported by NIH grant AR40544, the Arthritis Foundation, Pfizer Pharmaceutical and the Chicago Community Trust.

\section{References.}

Balbi, B., Moller, D.R., KiRBy, M., Holroyd, K.J. \& Crystal, R.G. (1990), Increased numbers of T lymphocytes with $\gamma \delta$-positive antigen receptors in a subgroup of individuals with pulmonary sarcoidosis. J. clin. Invest., 85, 1353-1361.

Berman, A., Espinoza, L.R., Diaz, J.D., Aguilar, J.L., Rolando, T., Vasey, F.B., Germain, B.F. \& Lockey, R.F. (1988), Rheumatic manifestations of human immunodeficiency virus infection. Amer. J. Med., 85, 59-64.

Brennan, F.M., Londei, M., Jackson, A.M., Hercend, T., Breniner, M.B., Maini, R.N. \& Feldmann, M. (1988a), T cells expressing $\gamma \delta$ chain receptors in rheumatoid arthritis. J. Autoimmun., 1, 319-326.

Brennan, F.M., Al.lard, S., Londei, M., Savill, C., Boylston, A., Cakrel, S., Maini, R.N. \& Feldmann, M. (1988b), Heterogeneity of T-ceil receptor idiotypes in rheumatoid arthritis. Clin. exp. Immunol., 73, 417-423.

Brenner, M.B., Mclean, J., Scheft, H., Riberdg, J., Ang, S., Seidman, J.G., Delvin, P. \& KRANGEL, M.S. (1987), Two forms of the T-cell receptor $r$ proteins found on peripheral blood cytotoxic T lymphocytes. Nature (Lond.), 325, 689-694.

Brown, J.H., Jardetzky, T, Saper, M.A., Samraoul, B., Bjorkman, P.J. \& Wiley, D.C. (1978), A hypothetical model of the foreign antigen binding site of class II histocompatibility molecules. Nature (Lond.), 332, 845-850.

Carponani, M., Cherchi, M., Paganelli, R., Giannini, G., Gall, E., Gaetano, C., Papet. TI, C. \& FIORILLI, M. (1990), Relative increase of $T$ cells expressing the gamma/delta rather than the alpha/beta receptor in ataxia-iclangiectasia. New Engl. $J$. Med., 322, 73-76.

Cassidy, J.T., Burt, A., Petty, R. \& Sull.jvan, D. (1969), Selective IgA deficicisy in connective tissue diseases. New Engl. J. Med., 280, 275.

Christadoss, P., Lindstrom, J.M., Mel.vold, R.W. \& TAl.1., N. (1985), Mutatior at I-A beta chain prevents experimental autoimmune myasthenia gravis. immunc: oneitics, 21 , 33-38.

Datta, S.K., PAtel, H. \& Berry, D. (1987), Induction of a cationic shift in IgG anti-DNA autoantibodies; role of $T$ helper cells with classical and novel phenotypes in three murine models of lupus nephritis. $J$. exp. Med., 165, $1252-1268$.

De Marif, D.A., Malnati, M., Moretta, A., Pende, D., Bottino, C., Casoratı, G., Cottafava, F., Melioli, G., Mingari, M.C., Migone, N., Romagnani, S. \& Moretta, L. (1987), CD3 ${ }^{+} 48^{-}$WT $31^{-}$(T-cell receptor $\gamma^{+}$) cells and other unusual phenotypes are frequently detected among spontaneously interleukin-2-responsive $T$ lymphocytes present in the joint fluid in juvenile rheumatoid arthritis. A clonal analysis. Europ. J. Immunol., 17, 1815-1819.

Del. Prete, G.F., Maggi, E., Mariotti, S., Tiri, A., Vercelli, D., Parronchi, P., Macchia, D., Pinchera, A., Ricci, M. \& Romagnani, S. (1986), Cytolytic T lymphocytes with natural killer activity in thyroid infiltrate of patients with Hashimoto's thyroiditis: analysis at clonal level. J. clin. Endocrinol. Metabol., 62, 1.

Depper, J.M. \& ZVAIFLeR, N.J. (1981), Epstein-Barr Virus; its relationship to the pathogenesis of rheumatoid arthritis. Arthritis Rheum., 24, 755-761.

Devey, M.E., Bleasdale, K. \& IsenBerg, D.A. (1987), Antibody affinity and IgG subclass of responses to tetanus toxoid in patients with rheumatoid arthritis and systemic lupus erythematosus. Clin. exp. Immunol., 68, 562-569. 
Duby, A.D., Sinclair, A.K Osenme Lawerence, S.L., Zeldes, W., Kan, L. \& Fox, D.A. (1989), Clonal hertroneity of synovial fluid T lymphocytes from patients with rheumato:d aithritis. Proc. nat. Acad. Sci. (Wash.), 86, 6206-6210.

Ferrick, D.A., Ohashi, P.S., Wallace, V., Schilham, M. \& Mak, T.W. (1989), Thymic ontogeny and selection of $\alpha \beta$ and $\gamma \delta \mathrm{T}$ cells. Immunol. Today, 10, 403-407.

Go, R.C.P., Alarcon, G.S., Acton, R.T., Koopian, W.J., VitTor, V.J. \& Barger, B.O. (1987), Analyses of HLA linkage in white families with multiple cases of seropositive rheumatoid arthritis. Arthritis Rheum., 30, 1115-1123.

Good, R.A., Rotstein, J. \& Mazzitelo, W.F. (1957), The stimultaneous occurrence of rheumatoid arthritis and agammag!obulinemia. J. Lab. Clin. Med., 49, 343.

Gregersen, P.K., Silver, J. \& W Winchester, R.J. (1987), The shared epitope hypothesis; an approach to understanding the molecular genetics of susceptibility to rheumatoid arthritis. Arthritis Rheum., 30, 1205-1213.

Happ, M.P., Kubo, R.T., Palmer, E., Born, W.K. \& O'Brien, R.L. (1989), Limited receptor repertoire in a mycobacteria-reactive subset of $\gamma \delta$ T lymphocytes. Nature (Lond.), 342, 696-698.

Haregewoin, A., Soman, G., Hom, R.C. \& FinberG, R.W. (1989), Human $\gamma \delta^{+}$T cells respond to mycobacterial heat-shock protein. Nature (Lond.), 340, 309-312.

Haynes, B.F., Grover, B.J., Whichard, L.P., Hale, L.P., Nunley, J.A., McCollum, D.E. \& Singer, K.H. (1988), Synovial microenvironment T-cell interactions; human T cells bind to fibroblast-like synovial cells in vitro. Arthritis Rheum., 31, 947-955.

Hodminott, S., Dornan, J., Bear, J.C. \& Farid, N.R. (1982), Immunoglobulin levels, immunodeficiency and HLA in type 1 (insulin-dependent) diabetes mellitus. Diabetologia, 23, 326-329.

Ioloshitz, J., NAPARstek, Y., Ben-Nun, A. \& Cohen, I.R. (1983), Lines of T lymphocytes induce or vaccinate against autoimmune arthritis. Science, 219, 56-58.

Holoshitz, J., Mattiau, M. \& Cohen, I.R. (1984), Arthritis induced in rat's by cloned T lymphocytes responsive to mycobacteria but not to collagen typ: II J. clin. Invest., 73, 211-215.

Holoshitz, J., Drucker, I., Yaretzky, A., Van Edev, W.. kilainaan, A., Lapidot, Z., FRENKEL, A. \& COHEN, I.R. (1986), T lymphocytes of rheumatoid arthritis patients show augmented reactivity to a fraction of mycobaiteria crossreactive with cartilage. Lancet, II, 305-309.

Holoshitz, J., VAN Eden, W., Frenkel, A. \& Cohe^, R. (1988), Autoimmune arthritis intuced by immunization to mycobacteria' suttectw, in 'Perspectives on autoimmunity" (I.R. Cohen) (pp. 155-164). CRC Press, Inc. West Palm Beach, FL.

Holoshitz, J., Koning, F., Colligan, J.E., De Brtyn, J. \& Strober, S. (1989), Isolation of $\mathrm{CD4}{ }^{-} \mathrm{CD}^{-}$mycobacteria-reactive $\mathrm{T}$ lymphocyte clones from rheumatoid arthritis synovial fluid. Nature (Lond.), 339, 226-229.

Janis, E.M., Kaufmann, S.H.E., SchwarTz, R.H. \& Pardoll, D.M. (1989), Activation of $\gamma \delta$ $T$ cells in the primary immune response to Mycobacterium tuberculosis. Science, 244, 713-716.

Jenkins, M.K., Schwartz, R.H. \& Pardoll, D.M. (1988), Effects of cyclosporine A on T-cell development and clonal deletion. Science, 241, 1655-1657.

Kabelitz, D., Bender, A., Schondelmaier, S., Schoel, B. \& Kaufmann, S.H.E. (1990), A large fraction of human peripheral blood $\gamma^{+}$T cells is activated by $M y c o b a c-$ terium tuberculosis but not by its 65 -kd heat shock protein. J. exp. Med., 171, 667-679.

Keystone, E.C., Minden, M., Klock, R., Poplonski, L., Zalcberg, J., Takadera, T. \& MAK, T.W. (1988), Structure of T-cell antigen receptor $\beta$ chain in synovial fluid cells from patients with rheumatoid arthritis. Arthritis Rheum., 31, 1555-1557.

Kitamura, K., Kiyono, H., Fujihashi, K., Eldridge, J.H., Green, D.R. \& McGhee, J.R. (1987), Contrasuppressor cells that break oral tolerance are antigen-specific T cells distinct from T helper (L3T4 +), T suppressor (Lyt-2) and B cells. J. Immunol., 139, 3251-3259.

Klareskog, L., Forsum, U., Scheynius, A., Kabelitz, D. \& Wigzell, H. (1982), Evidence in support of a self-perpetuating HLA-DR-dependent delayed-type cell reaction in rheumatoid arthritis. Proc. nat. Acad. Sci. (Wash.), 79, 3632-3636.

Kopelman, R.G. \& Zolla-Pazner, S. (1988), Associated of human immunodeficiency virus infection and autoimmune phenomena. Amer. J. Med., 84, 82-88.

Merryman, P.F., Crapper, R.M., Lee, S., Gregersen, P.K. \& Winchester, R.J. (1989), Class II major histocompatibility complex gene sequences in rheumatoid arthritis. Arthritis Rheum., 32, 251-258. 
Modlin, R.L., Pirmez, C., Hofman, F.M., Torigian, V., Uyemura, K., Rea, T.H., BLOOM, B.R. \& BRENNER, M.B. (1989), Lymphocytes bearing antigen-specific $\gamma \delta$ T-cell receptors accumulate in human infectious disease lesions. Nature (Lond.), 339, 544-548.

Morio, T., Nagasawa, N., Nonoyama, S., Okawa, H. \& Yata, J.-I. (1990), Phenotypic profile and functions of $T$-cell receptor $\gamma \delta$-bearing cells from patients with primary immunodeficiency syndrome. $J$. Immunol., 144, 1270-1275.

Morisset, J., Trannoy, E., De Talance, A., Spinella, S., Debre. P., Godet, P. \& Seman, M. (1988), Genetics and strain distribution of concanavalin A-reactive Ly-2-, L3T4peripheral precursors of autoreactive T cells. Europ. I. Immunol., 18, 387-394.

Nepom, G.T., Byers, P., Seyfried, C., Healey, L.A., Wilske, K.R., Stage, D. \& Nepom, B.S. (1989), HLA genes associated with rheumatoid arthritis; identification of susceptibility alleles using specific oligonucleotide probes. Arthritis Rheum., 32, 15-21.

O'Brien, R.L., Happ, M.P., Dallas, A., Palmer, E., Kubo, R. \& Born, W.K. (1989), Stimulation of a major subset of lymphocytes expressing T-cell receptor $\gamma \delta$ by an antigen derived from Mycobacterium tuberculosis. Cell, 57, 667-674.

Reme, T., Portier, M., Frayssinoux, F., Combe, B., Miossec, P., Favier, F. \& Sany, J. (1990), T-cell receptor expression and activation of synovial lymphocyte subsets in patients with rheumatoid arthritis. Arthritis Rheum., 33, 4.

Res, P.C., Breedveld, F.C., VAN Embden, J.D.A., DE VRIES, R.P.R., SchaAR, C.G., Van EDEN, W. \& COHEN, I.R. (1988), Synovial fluid T-cell reactivity against $65 \mathrm{kd}$ heat shock protein of mycobacteria in early chronic arthritis. Lancet, II, 478-480.

Roudier, J., Rhodes, G., Petersen, J., Vaughan, J.H. \& Carson, D.A. (1988), The EpsteinBarr virus glycoprotein gp1 10, a molecular link between HLA DR4, HLA DR1 and rheumatoid arthritis. Scand. J. Immunol., 27, 367-371.

SAKAGUChI, S. \& SAKAGUCHI, N. (1988), Thymus and autoimmunity; transplantation of the thymus from cyclosporin-A-treated mice causes organ-specific autoimmune disease in athymic nude mice. $J$. exp. Med., 167, 1479-1485.

Sakaguchi, S. \& Sakaguchi, N. (1989), Organ-specific autoimmune disease induced in mice by elimination of T-cell subsets. J. Immunol., 142, 471-480.

Savill, C.M., Delves, P.J., Kioussis, D., Walker, P., Lydyard, P.M., Colaco, B., SHIPLEY, M. \& RoITT, I.M. (1987), A minority of patients with rheumatoid arth ritis show a dominant rearrangement of T-cell receptor $\beta$-chain genes in $s ; n o v i a l ~ l y m-$ phocytes. Scand. J. Immunol., 25, 629-635.

Stamenkovic, I., Stegagno, M., Wright, K.A., Krane, S.M., Amento, E.P., Colvin, R.B., DuduESNoy, R.J. \& KuRNICK, J.T. (1988), Clonal dominance among T lymphocyte infiltrates in arthritis. Proc. nat. Acad. Sci. (Wash.), 85, 1179-1183.

Stastny, P. (1978), Association of the B-cell alloantigen DRw4 with theumatoid arthritis. HLA-DRw4 in rheumatoid arthritis. New Engl. J. Med., 298, 869-871.

Tanay, A., Field, E.H., HopPe, R.T. \& Strober, S. (1987), Long-term followup of rheumatoid arthritis patients treated with total lymphoid irradiation. Arthritis Rheum., 30, 1-10.

Trentham, D.E., Brahn, E., Williams, W., McCune, W.J. \& Belli, J.E. (1984), Connective tissue disease can develop in rats either spontaneously or after total lymphoid irradiation. $J$. Rheumatol., 11, 410-412.

Triebel, F., Faurl, F., Graziani, M., Jitcukawa, S., Lefranc, M.P. \& Hercend, T. (1988), A unique V-J-C rearranged gene encodes a $\gamma$ protein expressed on the majority of $\mathrm{CD3}^{+}$T-cell receptor $\alpha / \beta$ circulating lymphocytes. J. exp. Med., 167, 694-699.

VAN Eden, W., ThOle, J.E.R., VAN DER ZEE, R., NoORdZIJ, A., VAN EMBDEN, J.D.A., HENSEN, E.J. \& COHEN, I.R. (1988), Cloning of the mycobacterial apitope recognized by $T$ lymphocytes in adjuvant arthritis. Nature (Lond.), 331, 171-173. 